\title{
Effects of supplemental fish oil on resting metabolic rate, body composition, and salivary cortisol in healthy adults
}

\author{
Eric E Noreen*, Michael J Sass, Megan L Crowe, Vanessa A Pabon, Josef Brandauer, Lindsay K Averill
}

\begin{abstract}
Background: To determine the effects of supplemental fish oil (FO) on resting metabolic rate (RMR), body composition, and cortisol production in healthy adults.

Methods: A total of 44 men and women (34 $\pm 13 y$, mean+SD) participated in the study. All testing was performed first thing in the morning following an overnight fast. Baseline measurements of RMR were measured using indirect calorimetry using a facemask, and body composition was measured using air displacement plethysmography. Saliva was collected via passive drool and analyzed for cortisol concentration using ELISA. Following baseline testing, subjects were randomly assigned in a double blind manner to one of two groups: $4 \mathrm{~g} / \mathrm{d}$ of Safflower Oil (SO); or $4 \mathrm{~g} / \mathrm{d}$ of FO supplying 1,600 mg/d eicosapentaenoic acid (EPA) and $800 \mathrm{mg} / \mathrm{d}$ docosahexaenoic acid (DHA). All tests were repeated following 6 wk of treatment. Pre to post differences were analyzed using a treatment $X$ time repeated measures ANOVA, and correlations were analyzed using Pearson's r.
\end{abstract}

Results: Compared to the $\mathrm{SO}$ group, there was a significant increase in fat free mass following treatment with $\mathrm{FO}$ $(\mathrm{FO}=+0.5 \pm 0.5 \mathrm{~kg}, \mathrm{SO}=-0.1 \pm 1.2 \mathrm{~kg}, \mathrm{P}=0.03)$, a significant reduction in fat mass ( $\mathrm{FO}=-0.5 \pm 1.3 \mathrm{~kg}, \mathrm{SO}=+0.2$ $\pm 1.2 \mathrm{~kg}, \mathrm{P}=0.04$ ), and a tendency for a decrease in body fat percentage ( $\mathrm{FO}=-0.4 \pm 1.3 \%$ body fat, $\mathrm{SO}=+0.3 \pm$ $1.5 \%$ body fat, $\mathrm{p}=0.08$ ). No significant differences were observed for body mass ( $\mathrm{FO}=0.0 \pm 0.9 \mathrm{~kg}, \mathrm{SO}=+0.2 \pm$ $0.8 \mathrm{~kg}$ ), RMR ( $\mathrm{FO}=+17 \pm 260 \mathrm{kcal}, \mathrm{SO}=-62 \pm 184 \mathrm{kcal}$ ) or respiratory exchange ratio ( $\mathrm{FO}=-0.02 \pm 0.09, \mathrm{SO}=$ $+0.02 \pm 0.05$ ). There was a tendency for salivary cortisol to decrease in the $F O$ group ( $F O=-0.064 \pm 0.142 \mu \mathrm{g} / \mathrm{dL}$, $\mathrm{SO}=+0.016 \pm 0.272 \mu \mathrm{g} / \mathrm{dL}, \mathrm{p}=0.11)$. There was a significant correlation in the FO group between change in cortisol and change in fat free mass $(r=-0.504, p=0.02)$ and fat mass $(r=0.661, p=0.001)$.

Conclusion: 6 wk of supplementation with FO significantly increased lean mass and decreased fat mass. These changes were significantly correlated with a reduction in salivary cortisol following FO treatment.

\section{Background}

It is generally believed that a high-fat diet is a contributing factor to excess body fat accumulation due to the greater energy density of fat and the relative inability of the body to increase fat oxidation in the presence of over consumption of fats [1,2]. However, several rodent studies have shown clearly that diets rich in omega 3 fatty acids, specifically eicosapentaenoic acid (EPA) and docosahexaenoic acid (DHA), which are found in large amounts in the oil from cold-water fish, lead to

\footnotetext{
* Correspondence: enoreen@gettysburg.edu
Department of Health Sciences, Gettysburg College, Gettysburg

* Correspondence: enoreen@gettysburg.edu
Department of Health Sciences, Gettysburg College, Gettysburg Pennsylvania, USA
}

(c) 2010 Noreen et al; licensee BioMed Central Ltd. This is an Open Access article distributed under the terms of the Creative Commons Attribution License (http://creativecommons.org/licenses/by/2.0), which permits unrestricted use, distribution, and reproduction in any medium, provided the original work is properly cited. other fatty acids [3-7]. The exact mechanism(s) responsible for this phenomenon are not completely understood, but there are several possible explanations. For example, EPA and DHA are very effective at suppressing lipogenic gene expression $[8,9]$, thereby limiting the synthesis of lipids. EPA and DHA have also been found to increase the oxidation of lipids as a result of an increase in carnitine acyltransferase I (CAT 1) activity $[10,11]$, which allows greater fatty acid transport across the inner mitochondrial matrix via the carnitine-acylcarnitine translocase mechanism [12]. Additionally, EPA can increase mitochondrial lipid oxidation indirectly by inhibiting acetyl-CoA carboxylase [13], which is the 
enzyme that catalyzes the synthesis of malonyl CoA, and is a potent inhibitor of CAT I [14]. Moreover, EPA and DHA can also decrease the sensitivity of CAT I to malonyl CoA $[11,15]$ which may allow a higher rate of lipid oxidation across a variety of different metabolic states. It is also possible that omega 3 fatty acids may influence total body lipid accretion by increasing thermogenesis as a result of increased activity of uncoupling proteins and peroxisomes [16], and/or by increasing lean body mass $[3,5]$, which would indirectly increase thermogenesis.

Although there is some disagreement in the literature, there appears to be a negative effect of the stress hormone cortisol on body composition $[17,18]$. The welldocumented association between Cushing's disease and obesity [19] clearly shows that conditions that significantly increase cortisol levels can increase fat accretion. However, it is not known if treatments that lower cortisol levels can positively impact body composition. There is limited evidence that fish oil supplementation can reduce cortisol levels [20], which raises the possibility that the consumption of fish oil could decrease body fat $\%$ by decreasing cortisol levels. To date, no study has examined the relationship between salivary cortisol and body composition following treatment with fish oil.

Despite the mechanistic data and results in rodents, very little is known about the effects of omega 3 fatty acids on body composition and metabolic rate in humans. In the first study using humans, Couet et al. [21] found that when $6 \mathrm{~g} / \mathrm{d}$ of visible dietary fat was replaced with $6 \mathrm{~g} / \mathrm{d}$ of fish oil for $3 \mathrm{wk}$, there was a significant increase in fat oxidation as measured by RER, and a concomitant decrease in total body fat as measured by dual energy X-ray absorptiometry. There was also an increase in the resting metabolic rate, but this was no longer evident when the observed slight increase in lean mass during the fish oil treatment was accounted for, perhaps suggesting that fish oil may increase RMR by increasing lean mass. More recently, Hill et al. [22] found that supplementing the diet with fish oil significantly reduced fat mass compared to a control group supplemented with sunflower oil. Similarly, Thorsdottir et al. [23] found that including fish, or fish oil supplements, in a hypoenergetic diet resulted in greater weight loss in young overweight men compared to a hypoenergetic diet that did not include fish or fish oil.

The aim of the present study was 1) to determine the effects of supplemental fish oil on body composition and resting metabolic rate in healthy adults, and 2) to determine the effects of supplemental fish oil on morning salivary cortisol concentrations, and determine if there is a relationship between changes in salivary cortisol concentrations and changes in body composition following fish oil treatment.

\section{Methods}

Prior to all testing, approval for the study was obtained from the institutional review board at Gettysburg College and written informed consent was obtained from all subjects.

Healthy adults (18-55y) were recruited through flyers posted at Gettysburg College and surrounding community. Individuals who ate fatty fish at least 3 times a month, or were supplementing their diet with omega 3 fatty acids, or had a known metabolic or endocrine disorder were excluded. Subjects were healthy and active, but not engaged in consistent, systematic exercise training. In total, 44 individuals volunteered to participate (Table 1). Subjects were asked to maintain their current diet and exercise practices throughout the study.

\section{Experimental Protocol}

Subjects reported to the laboratory first thing in the morning following a 10-12 h overnight fast for RMR determination using open circuit indirect calorimetry $(\mathrm{n}=26)$ and body composition assessment using air dis-

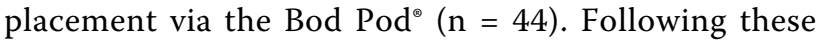
tests, a saliva sample was taken via passive drool and later analyzed for cortisol content. Subjects were then randomly assigned in a double blind manner to one of two groups:

Safflower oil (SO): $4 \mathrm{~g} / \mathrm{d}$ of safflower oil (Genuine Health Corporation, Toronto, Ontario, CA) administered in 4 enteric-coated capsules (each capsule provided $1 \mathrm{~g}$ of cold pressed, high linoleic acid, safflower oil).

Fish oil (FO): $4 \mathrm{~g} / \mathrm{d}$ concentrated fish oil (o3mega extra strength, Genuine Health Corporation, Toronto, Ontario, CA) administered in 4 enteric-coated capsules (each capsule provided $400 \mathrm{mg}$ EPA and 200 mg DHA).

Subjects took 2 capsules with breakfast and 2 capsules with dinner for a 6 wk period. All testing was repeated following 6 wk of supplementation.

\section{Body Composition}

Body composition was assessed by whole body densitometry using air displacement via the Bod $\mathrm{Pod}^{\circ}$ (Life Measurements, Concord, CA). All testing was done in accordance with the manufacturer's instructions as detailed elsewhere [24]. Briefly, subjects were tested wearing only tight fitting clothing (swimsuit or undergarments) and an acrylic swim cap. The subjects wore the exact same clothing for all testing. Thoracic gas volume was estimated for all subjects using a predictive equation integral to the Bod $\mathrm{Pod}^{\circ}$ software. The calculated value 
Table 1 Pre and Post values following 6 weeks of treatment with $4 \mathrm{~g} / \mathrm{d}$ of safflower oil, or $4 \mathrm{~g} / \mathrm{d}$ of fish oil

\begin{tabular}{|c|c|c|c|c|c|c|}
\hline & \multicolumn{3}{|c|}{ Safflower Oil } & \multicolumn{3}{|c|}{ Fish Oil } \\
\hline & Pre & Post & $\begin{array}{l}\text { Post-Pre } \\
\text { Difference }\end{array}$ & Pre & Post & $\begin{array}{l}\text { Post-Pre } \\
\text { Difference }\end{array}$ \\
\hline \multicolumn{7}{|l|}{ Sex } \\
\hline Male (n) & 8 & & & 6 & & \\
\hline Female (n) & 14 & & & 16 & & \\
\hline Age (y) & $\begin{array}{c}35 \pm 14 y \\
(29 ; 41)\end{array}$ & & & $\begin{array}{c}33 \pm 13 y \\
(27 ; 39)\end{array}$ & & \\
\hline Weight (kg) & $\begin{array}{c}71.1 \pm 15.2 \\
(64.7 ; 77.5) \\
\end{array}$ & $\begin{array}{c}71.3 \pm 15.3 \\
(65.1 ; 77.6) \\
\end{array}$ & $\begin{array}{l}0.2 \pm 0.8 \\
(-0.2 ; 0.6)\end{array}$ & $\begin{array}{c}71.3 \pm 14.4 \\
(65.1 ; 77.6) \\
\end{array}$ & $\begin{array}{c}71.3 \pm 13.7 \\
(65.1 ; 77.6) \\
\end{array}$ & $\begin{array}{l}0.0 \pm 0.9 \\
(-0.4 ; 0.4) \\
\end{array}$ \\
\hline Body Fat (\%) & $\begin{array}{l}27.7 \pm 10.6 \\
(23.0 ; 32.4)\end{array}$ & $\begin{array}{c}28.0 \pm 10.8 \\
(23.2 ; 32.8)\end{array}$ & $\begin{array}{c}0.3 \pm 1.5 \dagger \\
(-0.4 ; 1.0)\end{array}$ & $\begin{array}{l}30.5 \pm 7.7 \\
(26.7 ; 32.5)\end{array}$ & $\begin{array}{l}30.1 \pm 7.6 \\
(26.3 ; 33.9)\end{array}$ & $\begin{array}{c}-0.4 \pm 1.3 \dagger \\
(-1.2 ; 0.2)\end{array}$ \\
\hline Fat Mass (kg) & $\begin{array}{l}19.7 \pm 9.7 \\
(15.4 ; 24.0) \\
\end{array}$ & $\begin{array}{l}19.9 \pm 9.9 \\
(15.5 ; 24.3) \\
\end{array}$ & $\begin{array}{c}0.2 \pm 1.2^{*} \\
(-0.3 ; 0.7) \\
\end{array}$ & $\begin{array}{l}22.3 \pm 8.2 \\
(18.3 ; 25.7)\end{array}$ & $\begin{array}{l}21.8 \pm 7.6 \\
(18.2 ; 25.0)\end{array}$ & $\begin{array}{c}-0.5 \pm 1.3^{*} \\
(-1.1 ; 0.1)\end{array}$ \\
\hline Fat Free Mass (kg) & $\begin{array}{c}50.5 \pm 11.9 \\
(45.2 ; 55.5) \\
\end{array}$ & $\begin{array}{c}50.4 \pm 12.3 \\
(45.0 ; 55.8) \\
\end{array}$ & $\begin{array}{c}-0.1 \pm 1.2^{* *} \\
(-0.6 ; 0.4) \\
\end{array}$ & $\begin{array}{c}50.1 \pm 11.7 \\
(45.1 ; 55.1) \\
\end{array}$ & $\begin{array}{c}50.6 \pm 11.9 \\
(45.5 ; 55.6) \\
\end{array}$ & $\begin{array}{c}0.5 \pm 0.5^{* *} \\
(0.3 ; 0.8) \\
\end{array}$ \\
\hline Salivary Cortisol ( $\mu \mathrm{g} / \mathrm{dL})$ & $\begin{array}{c}0.305 \pm 0.240 \\
(0.212 ; 0.399) \\
\end{array}$ & $\begin{array}{c}0.321 \pm 0.311 \\
(0.217 ; 0.425) \\
\end{array}$ & $\begin{array}{c}0.016 \pm 0.272 \\
(-0.108 ; 0.140) \\
\end{array}$ & $\begin{array}{c}0.270 \pm 0.179 \\
(0.179 ; 0.361) \\
\end{array}$ & $\begin{array}{c}0.206 \pm 0.131 \\
(0.104 ; 0.308) \\
\end{array}$ & $\begin{array}{r}-0.064 \pm 0.142 \\
(-0.127 ;-0.002) \\
\end{array}$ \\
\hline RMR (24 h Kcal); $n=26$ & $\begin{array}{l}1290 \pm 295 \\
(1103 ; 1477)\end{array}$ & $\begin{array}{l}1228 \pm 277 \\
(1053 ; 1400)\end{array}$ & $\begin{array}{c}-62 \pm 184 \\
(-179 ; 55)\end{array}$ & $\begin{array}{l}1335 \pm 213 \\
(1200 ; 1470)\end{array}$ & $\begin{array}{l}1352 \pm 323 \\
(1147 ; 1557)\end{array}$ & $\begin{array}{l}17 \pm 260 \\
(-148 ; 152)\end{array}$ \\
\hline RER; $n=26$ & $\begin{array}{c}0.809 \pm 0.052 \\
(0.776 ; 0.842)\end{array}$ & $\begin{array}{l}0.832 \pm 0.41 \\
(0.806 ; 0.858)\end{array}$ & $\begin{array}{c}0.023 \pm 0.54 \\
(-0.011 ; 0.057)\end{array}$ & $\begin{array}{c}0.841 \pm 0.59 \\
(0.804 ; 0878)\end{array}$ & $\begin{array}{l}0.822 \pm 0.48 \\
(0.791 ; 0.853)\end{array}$ & $\begin{array}{c}-0.019 \pm 0.85 \\
(-0.073 ; 0.035)\end{array}$ \\
\hline
\end{tabular}

Data are expressed as means \pm SD (95\% confidence interval). Data were analyzed using a treatment $X$ time repeated measures ANOVA

* significant treatment $X$ time interaction, $p=0.04$

** significant treatment $X$ time interaction, $p=0.03$

$\dagger$ treatment $X$ time interaction, $p=0.08$

for body density was used in the Siri equation [25] to estimate body composition. A complete body composition measurement was performed twice, and if the body fat $\%$ was within $0.05 \%$ the two tests were averaged. If the two tests were not within $0.05 \%$ agreement, a third test was performed and the average of 3 complete trials was used for all body composition variables. All testing was completed first thing in the morning following a 10 $h$ overnight fast (water intake was allowed).

\section{Resting Metabolic Rate $(n=24)$}

For logistical reasons, metabolic testing was only performed on the first twelve subjects from each group $(\mathrm{n}=$ 24). Subjects refrained from caffeine consumption and vigorous exercise for $24 \mathrm{~h}$ prior to the resting metabolic rate (RMR) test. The subjects kept a detailed record of their food intake for the day prior to testing, and this was used to duplicate the diet for the day prior to all subsequent tests. Subjects transported themselves to the lab with the provision that they did not walk more than 100 meters total for their commute. Subjects rested in the supine position in a darkened room covered with a light blanket. A rubber face mask was used to collect expired gases for analysis via open circuit indirect calorimetry using a Medgraphics Ultima Cardio II breath-by-breath system that was calibrated prior to each test according to manufacturers specifications. (Medical Graphics Corporation, St.
Paul, MN, USA). While the subjects rested quietly, data were collected for $40 \mathrm{~min}$. The final $20 \mathrm{~min}$ of data collected was averaged and $24 \mathrm{~h}$ energy expenditure was calculated using the thermal equivalent of $\mathrm{O}_{2}$ consumed based on a non-protein RQ table [26].

\section{Salivary analysis}

Subjects rinsed their mouth with water prior to all saliva collections to minimize contamination of the samples. Saliva was collected in a polypropylene vial via passive drool through a short straw and stored at $-80^{\circ} \mathrm{C}$ until analysis. Prior to analysis, samples were thawed and centrifuged at $10,000 \mathrm{~g}$ for 20 minutes to remove mucins and analyzed for cortisol concentration using a commercially available enzyme immunoassay kit (Salimetrics, State College, PA, USA). Salivary cortisol is a sensitive marker of activation the hypothalamus-pituitary-adrenal system's response to stress and correlates very well with blood cortisol concentrations [27].

\section{Statistical Analysis}

Data were analyzed using the Statistical Package for the Social Sciences version 13 (SPSS Inc., Chicago, IL). A treatment by time, repeated measures ANOVA was used to evaluate significant differences, and a standard pearson's $r$ was used to evaluate correlations. For all analysis, the alpha level was set at $\mathrm{p} \leq 0.05$. 


\section{Results}

A total of 47 individuals volunteered to participate in this study. Two individuals withdrew from the study citing personal time conflicts, and one participant withdrew from the study as a result of a possible reaction to the safflower oil capsules. In general, both treatments were very well tolerated and no other side effects were noted for either group. Of particular importance, the enteric coating of the fish oil capsules prevented "fish burps," which are a common side effect often experienced with fish oil supplementation. A total of 44 subjects completed the study (Table 1).

\section{Body Composition}

Results from the body composition testing are presented in Table 1. There were no significant differences observed for body mass between the treatments $(\mathrm{SO}=$ $0.2 \pm 0.8 \mathrm{~kg} ; \mathrm{FO}=0.0 \pm 0.9 \mathrm{~kg} ; \mathrm{p}=0.52)$. However, there was a significant treatment by time interaction observed for fat free mass which means the change in fat free mass over time was significantly different between the treatments (Figure 1: $\mathrm{SO}=-0.1 \pm 1.2 \mathrm{~kg}$; $\mathrm{FO}=+0.5 \pm 0.5 \mathrm{~kg} ; \mathrm{p}=0.03)$. Similarly, there was a significant treatment by time interaction for fat mass as well (Figure 1: $\mathrm{SO}=0.2 \pm 1.2 \mathrm{~kg}$; FO $=-0.5 \pm 1.3 \mathrm{~kg}$; $\mathrm{p}$ $=0.04)$. Percent body fat also tended to change differently over time between the treatments ( $\mathrm{SO}=0.3 \pm$ $1.5 \%$ FO $=-0.4 \pm 1.3 \% ; \mathrm{p}=0.08$ ).

\section{Salivary Cortisol Concentrations}

There was a tendency for salivary cortisol concentrations to change differently over time between the two treatments $(\mathrm{SO}=0.016 \pm 0.272 \mu \mathrm{g} / \mathrm{dL} ; \mathrm{FO}=-0.072 \pm 0.142$

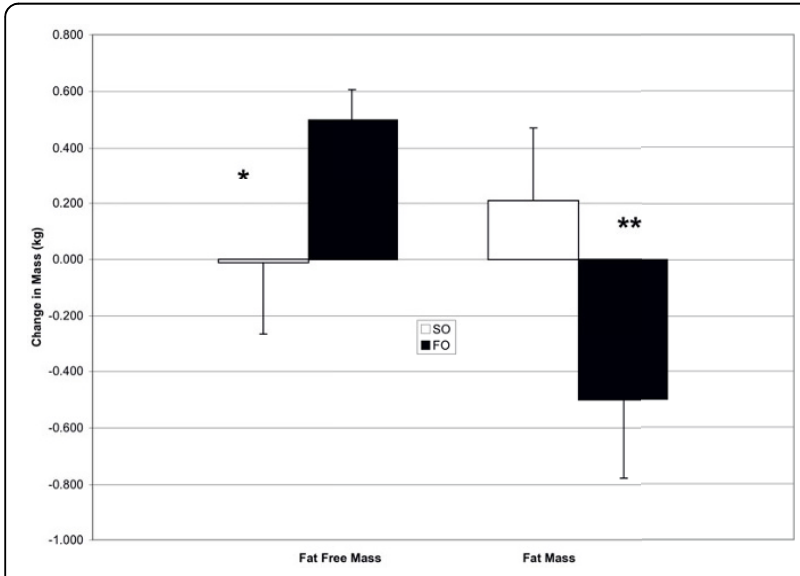

Figure 1 Change in fat mass and fat free mass following 6 wk of treatment with either $4 \mathrm{~g} / \mathrm{d}$ of safflower oil (SO), or $4 \mathrm{~g} / \mathrm{d}$ of fish oil (FO). Data are means \pm SEM. * significant treatment $X$ time interaction, $p=0.04$. ${ }^{*}$ significant treatment $X$ time interaction, $p=0.03$ $\mu \mathrm{g} / \mathrm{dL} ; \mathrm{p}=0.11)$. However, when a repeated measures $\mathrm{t}$ test was performed on the Pre and Post scores of each group independently, the SO change was not significant ( $p=0.79$ ), but the Post score was significantly lower than the Pre score in the FO group ( $\mathrm{p}=0.04)$. It is very likely that the reduced statistical power of the omnibus $F$ used in the repeated measures ANOVA resulted in a type II error, and the reduction in salivary cortisol concentrations following fish oil supplementation is a real effect. In support of this, the 95\% confidence interval of the PrePost difference in salivary cortisol concentration for the fish oil group (table 1) contains only negative values $(-0.127$ to $-0.002 \mu \mathrm{g} / \mathrm{dL})$, whereas the $95 \%$ confidence interval for the safflower oil group is centered around a mean difference value of essentially zero ( -0.108 to 0.14 $\mu \mathrm{g} / \mathrm{dL})$. Taken together, these additional statistics suggest that the reduction in salivary cortisol concentration observed in the fish oil group is a real effect.

The change in salivary cortisol concentration in the FO group was significantly correlated with the change in $\%$ body fat $(r=0.638, p=0.001)$, the change in fat free mass $(\mathrm{r}=-0.504, \mathrm{p}=0.02)$ as well as the change in fat mass $(r=0.661, p=0.001)$. No significant correlations were observed in the SO group between the change in salivary cortisol concentration and the change in $\%$ body fat $(\mathrm{r}=-0.321 ; \mathrm{p}=0.17)$, change in fat free mass $(r=0.007 ; p=0.98)$, or the change in fat mass $(\mathrm{r}=-0.309 ; \mathrm{p}=0.19)$.

\section{Metabolic Data}

No significant differences between groups were observed over time for resting metabolic rate $(\mathrm{SO}=-62 \pm 184$ $\mathrm{kcal}, \mathrm{FO}=17 \pm 260 \mathrm{kcal} ; \mathrm{p}=0.40)$, or for the respiratory exchange ratio $(\mathrm{SO}=0.023 \pm 0.54 ; \mathrm{FO}=-0.019 \pm$ $0.85, \mathrm{p}=0.16)$.

\section{Discussion}

The results of this study showed that 6 weeks of supplemental fish oil significantly increased lean mass, and significantly reduced fat mass in healthy adults. This is in agreement with Couet et al. [21], who observed a significant $0.88 \mathrm{~kg}$ reduction in fat mass, and a non-significant $0.20 \mathrm{~kg}$ increase in lean mass following 3 weeks of an increased consumption of fish oil. In their study, they added fish oil to the diet, but kept total fat and energy constant between the treatments. In the present study, the fish oil was added on top of an ad libitum diet, with instructions given to the subjects to maintain their normal dietary patterns throughout the study. Similarly, Hill et al [22] found a significant reduction in fat mass following 12 weeks of supplementation with fish oil in overweight subjects. They also observed an increase in lean mass in the fish oil group, however, like the data reported by Couet et al. [21], it did not reach 
significance. Thorsdottir et al. [23] recently found that supplementation with fish oil, or inclusion of fish in an energy-restricted diet resulted in significantly greater weight loss in young men. Additionally, they found that young men taking the fish oil supplements had a significantly greater reduction in waist circumference compared to the control group, or the group that increased their dietary intake of fish.

Unlike the Couet et al. study [21], we did not observe an increase in RMR, or a decrease in RER following fish oil treatment. The failure to find an increase in RMR following fish oil treatment is hard to explain given the significant increase in lean mass observed in the present study. Several studies have shown that lean mass is the largest determinant of RMR [28-30], and decreasing lean mass decreases RMR [31], while increasing lean mass increases RMR [32]. Therefore, it would be expected that the increase in lean mass would correspond to an increased RMR following fish oil treatment. In the Couet et al. study [21], metabolic data were measured for $45 \mathrm{~min}$ following a $90 \mathrm{~min}$ rest period. This is a longer time period than the $40 \mathrm{~min}$ used in the present study. However, it is doubtful that this methodological difference between the studies contributed to the differing effects observed for RMR and RER values since recent studies have shown that very short rest periods (as little as $5 \mathrm{~min}$ ) produce reproducible results that correlate extremely well with RMR measures made over much longer time periods $[33,34]$. It is also unlikely that the use of a subset $(n=24)$ of the total subject population can explain the failure to observe any metabolic changes since analysis of the 24 subjects found that they responded similar to the entire group in regards to body composition changes. It remains unclear why the increased lean mass observed following fish oil treatment did not correspond to an increase in RMR.

Intuitively it would make sense that if fat mass was reduced, but resting metabolic rate did not change following fish oil treatment, then the amount of calories coming from the oxidation of fatty acids should be increased. However, this was not the case in the present study. Although there was an absolute reduction in the RER following fish oil treatment (which would indicate an increased oxidation of fatty acids), the difference was not statistically significant. While it is possible that a type II error was committed and the reduction in RER was a real effect, it is also possible that the fish oil treatment increased fat oxidation at other times during the day such as during exercise [35], or during the postprandial period [36].

A potential shortcoming of the present study was not using dietary records to monitor the subjects' intake during the study. Although there are several potential problems with the use of dietary records (for a review of inaccuracies with self-recorded diet records see [37]), they would have provided us with some insight into the dietary habits of the subjects during the study. It therefore remains a possibility that the fish oil supplements resulted in the subjects changing their normal dietary habits. Although increasing dietary fat does not generally cause a decrease in voluntary fat intake [38], it has been shown that fish oil may reduce appetite [39], which could have led to the subjects consuming less total calories during the study. While a reduction in volitional food intake would explain the observed reduction in fat mass following fish oil treatment, it does not explain the increase in lean mass we observed.

Although other studies have observed a significant $[3,5]$, or insignificant $[21,22]$, increase in lean mass following fish oil treatment, to date no study has determined the mechanism by which dietary fish oil causes an increased accretion of lean mass. One possibility lies in the well-documented ability of dietary omega 3 fatty acids to reduce inflammatory cytokines [40], since inflammatory cytokines have the ability to increase protein degradation mainly by activating the ATP-ubiquitin-dependent pathway [41-45]. It is possible then, that dietary fish oil is simply decreasing the breakdown of protein tissue caused by inflammatory cytokines, and this results in an increased accretion of protein over time.

An alternative possibility is that fish oil supplementation was able to increase lean mass by reducing cortisol levels since it is well established that cortisol increases protein catabolism [46-49]. The significant negative correlation $(\mathrm{r}=-0.504, \mathrm{p}=0.02)$ observed in the fish oil group between the change in lean mass and the change in salivary cortisol concentrations would support this hypothesis. Although other studies have observed a decrease in cortisol levels following fish oil consumption [20], the exact mechanism(s) responsible are currently unknown. However, it is possible that the reduction of IL-6 as a result of fish oil consumption [50] is causing a reduction in cortisol production since it has been shown that IL-6 induces increases in cortisol levels [51,52]. It is unclear whether it is the well-documented ability of fish oil to reduce inflammatory cytokines, the reduction in cortisol, or a combination of both, that resulted in the increased lean mass observed in the present study following fish oil treatment. More work is needed to determine the mechanism(s) responsible for the accretion of lean mass following fish oil consumption.

The role of cortisol in obesity is poorly understood. Excessive cortisol levels, such as those observed in patients with Cushing's disease, results in substantial fat mass gains - especially in the abdominal region $[17,19]$. However, there is disagreement between studies about the relationship between values of cortisol that are 
within a normal physiological range, and obesity [18]. Nevertheless, several studies have shown an association with higher levels of cortisol and fat mass [53-58]. In the present study, there was a significant correlation between the change in salivary cortisol and the change in fat mass following fish oil treatment $(\mathrm{r}=0.661, \mathrm{p}=$ 0.001). Recent work by Purnell et al. [59] has shown that a reduction in fat mass as a result of dieting does not lower cortisol production, which would suggest that the relationship observed in the present study between salivary cortisol and fat mass was not simply a result of the reduction in fat mass. However, further work is needed to determine exactly how the reduction in cortisol levels may have influenced fat loss observed in the FO group.

In conclusion, 6 weeks of supplemental fish oil significantly increased lean mass, and significantly reduced fat mass in healthy adults. Given the short duration of this study, it is unclear how these changes would impact long-term body composition changes and more research is needed to determine the impact of chronic fish oil supplementation on long-term body composition. The reduction in salivary cortisol following fish oil treatment was significantly correlated with the increased fat free mass and the decreased fat mass observed. To the best of our knowledge, this is the first time that this association has been described in the literature. Since higher salivary cortisol levels are associated with higher mortality rates [60], the reduction in salivary cortisol levels observed in the present study following fish oil supplementation likely has significant implications beyond positive changes in body composition.

\section{Declaration of Competing interests}

The authors declare that they have no competing interests.

\section{Authors' contributions}

EEN was responsible for developing the concept and design of the study, data collection, statistical analysis and manuscript preparation. MJS, MLC, VAP and LKA contributed in the design of the study, data collection, and manuscript preparation. JB contributed with data analysis, statistical analysis, and manuscript preparation. All authors have read and approved the final draft of this manuscript.

\section{Acknowledgements}

Funding for this study was provided by a Gettysburg College Research and Professional Development Grant. The fish oil and safflower oil capsules were donated by Genuine Health Corporation, Toronto, Ontario, CA.

Received: 28 July 2010 Accepted: 8 October 2010

Published: 8 October 2010

\section{References}

1. Astrup A, Buemann B, Flint A, Raben A: Low-fat diets and energy balance: how does the evidence stand in 2002? Proc Nutr Soc 2002, 61:299-309.

2. Swinburn B, Ravussin E: Energy balance or fat balance? Am J Clin Nutr 1993, 57:766S-770S, discussion 770S-771S.

3. Su W, Jones PJ: Dietary fatty acid composition influences energy accretion in rats. J Nutr 1993, 123:2109-2114.
4. Baillie RA, Takada R, Nakamura M, Clarke SD: Coordinate induction of peroxisomal acyl-CoA oxidase and UCP-3 by dietary fish oil: a mechanism for decreased body fat deposition. Prostaglandins Leukot Essent Fatty Acids 1999, 60:351-356.

5. Hill JO, Peters JC, Lin D, Yakubu F, Greene H, Swift L: Lipid accumulation and body fat distribution is influenced by type of dietary fat fed to rats. Int J Obes Relat Metab Disord 1993, 17:223-236

6. Belzung F, Raclot T, Groscolas R: Fish oil n-3 fatty acids selectively limit the hypertrophy of abdominal fat depots in growing rats fed high-fat diets. Am J Physiol 1993, 264:R1111-1118.

7. Fickova M, Hubert $P$, Cremel G, Leray C: Dietary ( $n-3)$ and (n-6) polyunsaturated fatty acids rapidly modify fatty acid composition and insulin effects in rat adipocytes. J Nutr 1998, 128:512-519.

8. Jump DB, Clarke SD, Thelen A, Liimatta M: Coordinate regulation of glycolytic and lipogenic gene expression by polyunsaturated fatty acids. J Lipid Res 1994, 35:1076-1084.

9. Raclot T, Groscolas R, Langin D, Ferre P: Site-specific regulation of gene expression by $n-3$ polyunsaturated fatty acids in rat white adipose tissues. J Lipid Res 1997, 38:1963-1972.

10. Ide $T$, Kobayashi H, Ashakumary L, Rouyer IA, Takahashi $Y$, Aoyama T, Hashimoto T, Mizugaki M: Comparative effects of perilla and fish oils on the activity and gene expression of fatty acid oxidation enzymes in rat liver. Biochim Biophys Acta 2000, 1485:23-35.

11. Power GW, Newsholme EA: Dietary fatty acids influence the activity and metabolic control of mitochondrial carnitine palmitoyltransferase I in rat heart and skeletal muscle. J Nutr 1997, 127:2142-2150.

12. Lehninger $\mathrm{AL}$, Nelson DL, Cox MM: Principles of Biochemistry. Worth Publishers, New York 1993.

13. Willumsen N, Skorve J, Hexeberg S, Rustan AC, Berge RK: The hypotriglyceridemic effect of eicosapentaenoic acid in rats is reflected in increased mitochondrial fatty acid oxidation followed by diminished lipogenesis. Lipids 1993, 28:683-690.

14. Sidossis LS, Stuart CA, Shulman GI, Lopaschuk GD, Wolfe RR: Glucose plus insulin regulate fat oxidation by controlling the rate of fatty acid entry into the mitochondria. J Clin Invest 1996, 98:2244-2250.

15. Madsen L, Rustan AC, Vaagenes H, Berge K, Dyroy E, Berge RK: Eicosapentaenoic and docosahexaenoic acid affect mitochondrial and peroxisomal fatty acid oxidation in relation to substrate preference. Lipids 1999, 34:951-963.

16. Jaburek M, Varecha M, Gimeno RE, Dembski M, Jezek P, Zhang M, Burn P, Tartaglia LA, Garlid KD: Transport function and regulation of mitochondrial uncoupling proteins 2 and 3. J Biol Chem 1999, 274:26003-26007.

17. Bjorntorp P, Rosmond R: Obesity and cortisol. Nutrition 2000, 16:924-936.

18. Bose M, Olivan B, Laferrere B: Stress and obesity: the role of the hypothalamic-pituitary-adrenal axis in metabolic disease. Curr Opin Endocrinol Diabetes Obes 2009, 16:340-346.

19. Geer EB, Shen W, Gallagher D, Punyanitya M, Looker HC, Post KD, Freda PU: MRI Assessment of Lean and Adipose Tissue Distribution in Female Patients with Cushing's Disease. Clin Endocrinol (Oxf) 2010.

20. Delarue J, Matzinger O, Binnert C, Schneiter P, Chiolero R, Tappy L: Fish oil prevents the adrenal activation elicited by mental stress in healthy men. Diabetes Metab 2003, 29:289-295.

21. Couet C, Delarue P, Autoine JM, Lamisse F: Effect of dietary fish oil on body mass and basal fat oxidation in healthy adults. Int J Obes 1997, 21:637-643.

22. Hill AM, Buckley JD, Murphy KJ, Howe PR: Combining fish-oil supplements with regular aerobic exercise improves body composition and cardiovascular disease risk factors. Am J Clin Nutr 2007, 85:1267-1274.

23. Thorsdottir I, Tomasson H, Gunnarsdottir I, Gisladottir E, Kiely M, Parra MD, Bandarra NM, Schaafsma G, Martinez JA: Randomized trial of weight-lossdiets for young adults varying in fish and fish oil content. Int $J$ Obes (Lond) 2007, 31:1560-1566.

24. Dempster $P$, Aitkens $S: A$ new air displacement method for the determination of human body composition. Med Sci Sports Exerc 1995, 27:1692-1697.

25. Siri WE: Body composition from fluid spaces and density: analysis of methods. In Techniques for measuring body composition. Edited by: Brozek J, Henschel A. Washington, DC: National Academeny of Sciences, National Research Council; 1961:223-244.

26. Zuntz H: Pflugers Arch Physiol 1901, 83:557 
27. Hellhammer DH, Wust S, Kudielka BM: Salivary cortisol as a biomarker in stress research. Psychoneuroendocrinology 2009, 34:163-171

28. Gallagher D, Belmonte D, Deurenberg P, Wang Z, Krasnow N, Pi-Sunyer FX, Heymsfield SB: Organ-tissue mass measurement allows modeling of REE and metabolically active tissue mass. Am J Physiol 1998, 275:E249-258.

29. Illner K, Brinkmann G, Heller M, Bosy-Westphal A, Muller MJ: Metabolically active components of fat free mass and resting energy expenditure in nonobese adults. Am J Physiol Endocrinol Metab 2000, 278:E308-315.

30. Rodriguez G, Moreno LA, Sarria A, Pineda I, Fleta J, Perez-Gonzalez JM, Bueno M: Determinants of resting energy expenditure in obese and non-obese children and adolescents. J Physiol Biochem 2002, 58:9-15.

31. Bosy-Westphal A, Eichhorn C, Kutzner D, Illner K, Heller M, Muller MJ: The age-related decline in resting energy expenditure in humans is due to the loss of fat-free mass and to alterations in its metabolically active components. J Nutr 2003, 133:2356-2362.

32. Byrne HK, Wilmore $\mathrm{JH}$ : The effects of a 20-week exercise training program on resting metabolic rate in previously sedentary, moderately obese women. Int I Sport Nutr Exerc Metab 2001, 11:15-31.

33. Horner NK, Lampe JW, Patterson RE, Neuhouser ML, Beresford SA, Prentice RL: Indirect calorimetry protocol development for measuring resting metabolic rate as a component of total energy expenditure in free-living postmenopausal women. J Nutr 2001, 131:2215-2218.

34. Petros $S$, Engelmann L: Validity of an abbreviated indirect calorimetry protocol for measurement of resting energy expenditure in mechanically ventilated and spontaneously breathing critically ill patients. Intensive Care Med 2001, 27:1164-1168.

35. Huffman DM, Michaelson JL, Thomas TR: Chronic supplementation with fish oil increases fat oxidation during exercise in young men. JEPonline $2004,7$.

36. Delarue J, Couet C, Cohen R, Brechot JF, Antoine JM, Lamisse F: Effects of fish oil on metabolic responses to oral fructose and glucose loads in healthy humans. Am J Physiol 1996, 270:E353-362.

37. Schoeller DA, Bandini LG, Dietz WH: Inaccuracies in self-reported intake identified by comparison with the doubly labelled water method. Can J Physiol Pharmacol 1990, 68:941-949.

38. Saltzman E, Dallal GE, Roberts SB: Effect of high-fat and low-fat diets on voluntary energy intake and substrate oxidation: studies in identical twins consuming diets matched for energy density, fiber, and palatability. Am J Clin Nutr 1997, 66:1332-1339.

39. Parra D, Ramel A, Bandarra N, Kiely M, Martinez JA, Thorsdottir I: A diet rich in long chain omega-3 fatty acids modulates satiety in overweight and obese volunteers during weight loss. Appetite 2008, 51:676-680.

40. Calder PC: Polyunsaturated fatty acids and inflammation. Prostaglandins Leukot Essent Fatty Acids 2006, 75:197-202.

41. Llovera M, Garcia-Martinez C, Lopez-Soriano J, Carbo N, Agell N, LopezSoriano FJ, Argiles JM: Role of TNF receptor 1 in protein turnover during cancer cachexia using gene knockout mice. Mol Cell Endocrinol 1998, 142:183-189.

42. Llovera M, Carbo N, Lopez-Soriano J, Garcia-Martinez C, Busquets S, Alvarez B, Agell N, Costelli P, Lopez-Soriano FJ, Celada A, Argiles JM: Different cytokines modulate ubiquitin gene expression in rat skeletal muscle. Cancer Lett 1998, 133:83-87.

43. Llovera M, Garcia-Martinez C, Lopez-Soriano J, Agell N, Lopez-Soriano FJ, Garcia I, Argiles JM: Protein turnover in skeletal muscle of tumourbearing transgenic mice overexpressing the soluble TNF receptor-1. Cancer Lett 1998, 130:19-27.

44. Llovera M, Garcia-Martinez C, Agell N, Lopez-Soriano FJ, Argiles JM: TNF can directly induce the expression of ubiquitin-dependent proteolytic system in rat soleus muscles. Biochem Biophys Res Commun 1997, 230:238-241.

45. Llovera M, Carbo N, Garcia-Martinez C, Costelli P, Tessitore L, Baccino FM, Agell N, Bagby GJ, Lopez-Soriano FJ, Argiles JM: Anti-TNF treatment reverts increased muscle ubiquitin gene expression in tumour-bearing rats. Biochem Biophys Res Commun 1996, 221:653-655.

46. Brillon DJ, Zheng B, Campbell RG, Matthews DE: Effect of cortisol on energy expenditure and amino acid metabolism in humans. Am J Physiol 1995, 268:E501-513.

47. Simmons PS, Miles JM, Gerich JE, Haymond MW: Increased proteolysis. An effect of increases in plasma cortisol within the physiologic range. J Clin Invest 1984, 73:412-420.
48. Paddon-Jones D, Sheffield-Moore M, Cree MG, Hewlings SJ, Aarsland A, Wolfe RR, Ferrando AA: Atrophy and impaired muscle protein synthesis during prolonged inactivity and stress. J Clin Endocrinol Metab 2006, 91:4836-4841.

49. Paddon-Jones D, Sheffield-Moore M, Creson DL, Sanford AP, Wolf SE, Wolfe RR, Ferrando AA: Hypercortisolemia alters muscle protein anabolism following ingestion of essential amino acids. Am J Physiol Endocrinol Metab 2003, 284:E946-953.

50. Wigmore SJ, Fearon KC, Maingay JP, Ross JA: Down-regulation of the acute-phase response in patients with pancreatic cancer cachexia receiving oral eicosapentaenoic acid is mediated via suppression of interleukin-6. Clin Sci (Lond) 1997, 92:215-221.

51. Bethin KE, Vogt SK, Muglia L: Interleukin-6 is an essential, corticotropinreleasing hormone-independent stimulator of the adrenal axis during immune system activation. Proc Natl Acad Sci USA 2000, 97:9317-9322.

52. Steensberg A, Fischer CP, Keller C, Moller K, Pedersen BK: IL-6 enhances plasma IL-1ra, IL-10, and cortisol in humans. Am J Physiol Endocrinol Metab 2003, 285:E433-437.

53. Epel ES, McEwen B, Seeman T, Matthews K, Castellazzo G, Brownell KD, Bell J, Ickovics JR: Stress and body shape: stress-induced cortisol secretion is consistently greater among women with central fat. Psychosom Med 2000, 62:623-632.

54. Korbonits M, Trainer PJ, Nelson ML, Howse I, Kopelman PG, Besser GM, Grossman AB, Svec F: Differential stimulation of cortisol and dehydroepiandrosterone levels by food in obese and normal subjects: relation to body fat distribution. Clin Endocrinol (Oxf) 1996, 45:699-706.

55. Rosmond R, Bjorntorp P: Occupational status, cortisol secretory pattern, and visceral obesity in middle-aged men. Obes Res 2000, 8:445-450.

56. Rosmond R, Dallman MF, Bjorntorp P: Stress-related cortisol secretion in men: relationships with abdominal obesity and endocrine, metabolic and hemodynamic abnormalities. J Clin Endocrinol Metab 1998, 83:1853-1859.

57. Vogelzangs N, Beekman AT, Dik MG, Bremmer MA, Comijs HC, Hoogendijk WJ, Deeg DJ, Penninx BW: Late-life depression, cortisol, and the metabolic syndrome. Am J Geriatr Psychiatry 2009, 17:716-721.

58. Wallerius S, Rosmond R, Ljung T, Holm G, Bjorntorp P: Rise in morning saliva cortisol is associated with abdominal obesity in men: a preliminary report. J Endocrinol Invest 2003, 26:616-619.

59. Purnell JQ, Kahn SE, Samuels MH, Brandon D, Loriaux DL, Brunzell JD: Enhanced cortisol production rates, free cortisol, and 11beta-HSD-1 expression correlate with visceral fat and insulin resistance in men: effect of weight loss. Am J Physiol Endocrinol Metab 2009, 296:E351-357.

60. Schoorlemmer RM, Peeters GM, van Schoor NM, Lips P: Relationships between cortisol level, mortality and chronic diseases in older persons. Clin Endocrinol (Oxf) 2009, 71:779-786.

doi:10.1186/1550-2783-7-31

Cite this article as: Noreen et al:: Effects of supplemental fish oil on resting metabolic rate, body composition, and salivary cortisol in healthy adults. Journal of the International Society of Sports Nutrition 2010 7:31.

\section{Submit your next manuscript to BioMed Central and take full advantage of:}

- Convenient online submission

- Thorough peer review

- No space constraints or color figure charges

- Immediate publication on acceptance

- Inclusion in PubMed, CAS, Scopus and Google Scholar

- Research which is freely available for redistribution

Submit your manuscript at www.biomedcentral.com/submit
Ciomed Central 